\title{
Influence of initial milk yield, sward height and concentrate level on herbage intake and grazing behaviour of dairy cattle
}

\author{
R Pulido, JD Leaver
}

\author{
Wye College, University of London, Wye, Ashford, Kent, TN25 5AH, UK
}

The objective was to investigate how the milk yield potential of the cows influenced the interrelationship of the sward height, concentrate input and various dependent variables.

Two experiments of 42 and 24 days in spring and mid-summer were carried out with 45 and 27 Holstein Friesian cows respectively. In spring, five groups of initial milk yield (IMY) $16.9,21.1,28.0,31.5$ and $35.5 \mathrm{~kg} /$ day and in mid-summer three groups of IMY 22.2, 26.8 and $31.8 \mathrm{~kg} /$ day were used. Three sward heights $(\mathrm{SH})$ of $3-5 \mathrm{~cm}, 5-7 \mathrm{~cm}$ and $7-9 \mathrm{~cm}$ and three concentrate ( $160 \mathrm{~g} \mathrm{CP} / \mathrm{kg} \mathrm{DM}$ ) levels (Cl) of 0,3 and $6 \mathrm{~kg} /$ day were offered. The grazing area was 7.9 ha of a perennial ryegrass dominated long-term ley. The cows were grazed in three $\mathrm{SH}$ groups, and were continuously grazed.

Herbage intake (HDMI) and total dry matter intake (TDMI) were estimated indirectly from energy requirements measured from individual cow performance (Leaver, 1982, Herbage
Intake Handbook). Grazing time (GT), rumination time (RUMT) and resting time (REST) were recorded by 24 hour observations. The data were subjected to multiple regression analyses relating intake and behavioural dependent variables to the independent variables IMY, $\mathrm{SH}$ and $\mathrm{Cl}$.

The coefficients indicate that in experiments 1 and 2 respectively, HDMI increased by 0.34 and $0.31 \mathrm{~kg} /$ day per $1 \mathrm{~cm}$ increase in the sward height ; reduced by 1.01 and 0.78 $\mathrm{kg} /$ day per $\mathrm{kg}$ increase in concentrate; and increased by 0.18 and $0.29 \mathrm{~kg} / \mathrm{day}$ per $\mathrm{kg}$ increase in cow initial yield. Grazing, ruminating and resting behaviour were mainly influenced by the sward height.

There was no significant interaction between $\mathrm{SH}$ and $\mathrm{Cl}$, and the HDMl response to milk yield averaged only $0.24 \mathrm{~kg} \mathrm{DM} / \mathrm{kg}$ milk yield (2.8 MJ ME/kg milk yield). This emphasises the problems of maintaining milk yield of high potential cows even at high sward heights combined with concentrate supplementation.

\begin{tabular}{|c|c|c|c|c|c|c|}
\hline & Constant & $\mathrm{SH}$ & $\mathrm{Cl}$ & IMY & $\mathrm{R}^{2}$ & Sig \\
\hline \multicolumn{7}{|l|}{ Spring } \\
\hline HDMI (kg/day) & 6.93 & 0.341 & -1.01 & 0.184 & 87.2 & $\hbar \star \star \star$ \\
\hline TDMI (kg/day) & 6.93 & 0.341 & -0.136 & 0.184 & 67.1 & $* \star *$ \\
\hline $\mathrm{GT}(\min )$ & 569 & -24.2 & -3.84 & 4.19 & 47.6 & $\star \star \star \star$ \\
\hline RUMT (min) & 242 & 16.8 & 0.92 & 1.15 & 24.0 & * \\
\hline REST (min) & 500 & 6.62 & 2.61 & -5.13 & 37.7 & * \\
\hline \multicolumn{7}{|l|}{ Mid-summer } \\
\hline HDMI (kg/day) & 6.06 & 0.312 & -0.778 & 0.286 & 78.8 & 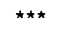 \\
\hline TDMI (kg/day) & 6.06 & 0.312 & 0.102 & 0.286 & 51.4 & $* * *$ \\
\hline GT (min) & 609 & -43.6 & 0.37 & 4.41 & 53.4 & $\star \star \star \star$ \\
\hline RUMT (min) & 372 & 21.1 & -2.40 & 0.05 & 21.9 & $\star \star \star \star$ \\
\hline REST (min) & 330 & 22.5 & 2.02 & -4.48 & 22.3 & $* * *$ \\
\hline
\end{tabular}

